\title{
THE UNIVERSITY OF KANSAS
}

\section{PALEONTOLOGICAL CONTRIBUTIONS}

\section{INDUCED COLOR IN OSTRACODE SHELLS: AN EXPERIMENTAL STUDY}

\author{
Mervin Kontrovitz, Nigel R. Ainsworth, Richard D. Burnett, and Jerry Marie Slack \\ Department of Geosciences, Northeast Louisiana University, Monroe, Louisiana 71209 U.S.A. \\ Paleo Services Ltd., Paramount Industrial Estate, Sandown Road, Watford, Herts WD2 4XA ENGLAND \\ Department of Geology, Trinity College, Dublin 2 IRELAND \\ Bossier Parish Community College, Bossier City, Louisiana 71111 U.S.A.
}

\begin{abstract}
Color alteration and the origins of the dark colors in ostracode shells were investigated. Modern shells were subjected to temperatures and pressures (T-P) simulating some burial conditions. Fossil shells were heated and immersed in solvents in an attempt to identify the coloring agents.

Shells of modern, marine ostracodes are white to pale yellow (Munsell 5Y 8/1 to 2.5Y 8/4). Upon heating, up to $650^{\circ} \mathrm{C}$, they became slightly redder, darker, and less color-saturated but never dark (that is, they had Munsell value greater than 5). Above $650^{\circ} \mathrm{C}$ they became even lighter and more yellow, and above $850^{\circ} \mathrm{C}$ still more yellow and chalky. Shells at elevated T-P with organic-poor sediments or iron compounds developed higher color values and low chromas but did not become dark. Only those heated in organicrich sediment and crude oil became dark (grays, browns, and blacks), resembling fossils from some outcrops and wells.

Shells near igneous intrusions have dark colors, and the darkness and color-saturation of fossils in metamorphic rocks correlate with increasing paleotemperatures. Reheated dark fossils lighten at about 375 to $450^{\circ} \mathrm{C}$; the coloring agent was driven off. This and the fact that modern ostracodes develop dark colors only when heated in organic-rich substances support the contention that the dark color originates from extraneous organic materials. The colors seem diagnostic of T-P and sediment and present the possibility of their use in reconstructing paleotemperature.
\end{abstract}

Key words: Ostracoda, shell color, diagenesis, paleotemperature, experimental, low-grade metamorphism.

\section{INTRODUCTION}

Interpretations of geologic history based on fossils would be enhanced if taphonomic processes were better known. Included in such processes are induced color changes that take place in shells and other durable parts of organisms (Tway et al., 1986). Conodonts and pollen are well known in this regard; their color changes have been carefully studied, and systems have been devised to interpret the thermal history of the fossils and the containing rock or sediment (Epstein et al., 1977; Rejebian et al., 1987; Wilson, 1961). Similar applications for microscopic calcareous shells have been the subject of recent studies that are still in their early stages (Kontrovitz et al., 1988; Kontrovitz et al., 1989).

Unlike previous articles on ostracodes, the present study addresses color alteration under temperatures and pressures (T-P) that simulate some conditions of diagenesis and metamorphism. Various types of sediment were used, thereby introducing another variable.

\section{MATERIALS AND METHODS}

Modern, unaltered, marine ostracodes (Oertli, 1971) from Florida Bay, U.S.A., and the beach of Rimini on the Adriatic Coast of Italy were used. Modern, freshwater 
Table 1. Modern taxa used in experiments to induce color.

Peratocytheridea setipunctata (Brady)*
Cytherura sandbergi Morales*
Xestoleberis sp.*
Loxocorniculum fusheri (Brady)*
Radimella sp.*
"Hemicytherideis" elongata (Brady) $†$
Cytheretta judaea (Brady) $†$
Loxoconcha rubritincta Ruggieri†
Hiltermannicythere turbida (Müller) $†$
Candona sp. +
Ilyocypris sp. +
Cypridopsis sp. +
* Florida Bay, Florida Keys, U.S.A.
† Beach of Rimini, Italy
+ Bayou Desiard (freshwater), Monroe, Louisiana,U.S.A.

forms were obtained from Bayou Desiard at Northeast Louisiana University (NLU), Monroe, Louisiana (Table 1). Fossils were recovered from outcrops in northeastern Spain and boreholes in Mesozoic and Tertiary rocks from Zaire, Gabon, Senegal, and Irish and United Kingdom offshore areas (see Ainsworth et al., 1990).

Tests at atmospheric pressure were done in an oven and furnace on a platinum substrate with or without sediment. Diagenetic and metamorphic changes were better simulated at elevated T-P in reactor vessels (Temp-Pres MRA-114S) with appropriate volumes of water or crude oil and water to obtain the desired pressures. Heating was done with flexible heating tapes (Thermoline, 312 watts) wrapped around the vessels, with a proportional electronic temperature controller (Versatherm Model 3156-4) and independent thermocouples used to control and monitor temperatures within less than $2^{\circ} \mathrm{C}$ of the desired setting. [See Kontrovitz et al. (1982) for details of the methodology.]

For most experiments with reactor vessels, T-P increments of $30^{\circ} \mathrm{C}$ and 100 atmospheres (atm.) were used throughout the range of 120 to $300^{\circ} \mathrm{C}$ and 400 to 1000 atm. These approximate T-P average values for burial depths of 4 to $10 \mathrm{~km}$ (Garrels \& Mackenzie, 1971); other T-P combinations are given in Tables 2, 4, 8, 9, 12, and 13 .

Experiments with shells in reactor vessels were done with $0.25 \mathrm{~g}$ of sediment, which included pure quartz, calcite, or a chlorite, illite, and mixed layer illite-smectite clay (herein called Elf clay). Some trials included mixtures of the sediments and other materials mentioned below, including organic-rich, natural sediment from the freshwater Bayou Desiard, which contains 12.8 percent organics (loss on ignition; Gross, 1971). After each experiment, shells and sediment were recovered from the vessels and airdried; the shells were then isolated for examination.

The authors speculated that petroleum may be a coloring agent for calcareous shells; this was based on their finding colored ostracode shells in petroliferous rocks.
Therefore, a series of tests was performed with crude oil at elevated temperatures at atmospheric and higher pressures.

Colors of treated and untreated shells were described with the standard Munsell Soil Color Charts (1988). On these charts color is the combination of hue, value, and chroma, each of which has a separate notation. The notation for hue gives its relation to red, yellow, green, blue, and purple; the notation for value indicates its lightness; and the notation for chroma indicates its strength (or "departure from a neutral of the same lightness"). For example, in the Munsell notation 5YR $8 / 3$, hue is given by $5 Y R$; value is 8 ; and chroma is 3 .

In addition to the color charts with standard notations for hue, value, and chroma, Munsell provides accompanying cards with names of colors of soils. These cards give such names as white and olive gray, which correspond to fields represented by the standard notations. The names, however, are less precise than the notations; for example, light gray is used both to summarize areas that include several different standard notations on a single card and for areas on several different cards. This is shown by the colors designated by standard notation as 5YR 7/1 and 5Y $7 / 2$, which are both named light gray even though 5YR 7/ 1 is redder and the less color saturated of the two. It is suggested that the reader will find it useful to have the color and name charts at hand while reading this paper.

Shells were placed on a Munsell standard, gray masking card and viewed through a Wild M-5 binocular, stereomicroscope set at a magnification of $20 \mathrm{X}$. The stage was illuminated by two American Optical model 651 lamps, each set at intensity level 2, about $15 \mathrm{~cm}$ from the specimens. One lamp was placed on each side of the microscope stage, so that the two lights and the specimen were on a straight line parallel with the front of the stage.

Fossil shells were examined, subjected to heating, and immersed in organic solvents in an attempt to gain information about the coloring agents. Colors of fossils from

Table 2. Colors of modern, marine ostracode shells after 48 hours at temperature listed and atmospheric pressure.

\begin{tabular}{ccc}
\hline \hline Temp. $\left({ }^{\circ} \mathrm{C}\right)$ & Munsell notation & Color \\
\hline 100 & $5 Y 7.5 / 2$ & light gray \\
200 & 5 YR $6.5 / 2$ & pinkish gray \\
reddish gray \\
$250-275$ & 5 YR $5.5 / 2$ & gray \\
$375-425$ & 5 YR $5.5 / 1$ & gray \\
$475-525$ & 5 YR $5.5 / 1$ & gray \\
$575-625$ & 5 YR $5.5 / 1$ & white \\
$650-675$ & 5 YR $8 / 1$ & white \\
$685-735$ & 10 YR $8 / 1$ to 10 YR $9 / 1$ & light gray \\
$775-825$ & 10 YR $9 / 1$ to 10 YR $7.5 / 2$ & white to light gray \\
$875-925$ & $2.5 Y 7.5 / 2$ & light gray \\
$975-1025$ & $5 Y 7.5 / 1.5$ &
\end{tabular}


Table 3. Colors of modern, marine ostracode shells subjected for 48 hours to the temperature and pressure (T-P) indicated, in the sediments listed.

\begin{tabular}{cccc}
\hline \hline T-P $\left({ }^{\circ} \mathrm{C}\right.$, Atm. $)$ & Quartz & Calcite & Elf clay \\
\hline 120,400 & $5 \mathrm{Y} 8 / 1$ (white) & $2.5 \mathrm{Y} 7 / 4$ (pale yellow) & $2.5 \mathrm{Y} 8 / 0$ (white) \\
150,500 & $5 \mathrm{YR} 8 / 1$ (white) & $2.5 \mathrm{Y} 8 / 0$ (white) & $2.5 \mathrm{Y} 8 / 2$ (white) \\
180,600 & $5 \mathrm{Y} 8 / 1$ (white) & $2.5 \mathrm{Y} 8 / 0$ (white) & $2.5 \mathrm{Y} 7 / 2$ (white) \\
210,700 & $5 \mathrm{Y} 8 / 1$ (white) & $2.5 \mathrm{Y} 6.5 / 4$ (light yellowish brown) & $2.5 \mathrm{Y} 8 / 2$ (white) \\
240,800 & $5 \mathrm{Y} 8 / 1$ (white) & $2.5 \mathrm{Y} 8 / 2$ (white) & $2.5 \mathrm{Y} 8 / 0$ (white) \\
270,900 & $5 \mathrm{Y} 7.5 / 1$ (light gray) & $5 \mathrm{YR} 8 / 1$ (white) & $2.5 \mathrm{Y} 7.5 / 2$ (light gray) \\
300,1000 & $5 \mathrm{Y} 9 / 1$ (white) & $2.5 \mathrm{Y} 6 / 2$ to $2.5 \mathrm{Y} 8 / 0$ (light brownish gray) & $2.5 \mathrm{Y} 7.5 / 2$ (light gray) \\
\hline
\end{tabular}

Table 4. Colors of modern, marine ostracode shells subjected for 48 hours to T-P listed, in $25 \%$ calcite and $75 \%$ quartz.

\begin{tabular}{|c|c|c|c|c|c|}
\hline T-P $\left({ }^{\circ} \mathrm{C}\right.$, Atm. $)$ & Color & P (Atm.) & Color & $\mathrm{P}$ (Atm.) & Color \\
\hline 120,400 & 10YR $7.5 / 2.5$ (light gray) & 200 & $2.5 Y 7.5 / 2$ (light gray) & & \\
\hline 150,500 & $10 \mathrm{YR} 8 / 3$ (very pale yellow) & 200 & $5 Y 9 / 1$ (white) & & \\
\hline 180,600 & 10YR $6.5 / 2$ (light gray brown) & 200 & $5 Y 8 / 1$ (white) & & \\
\hline 210,700 & 10YR $8 / 1$ (white) & 200 & $5 Y 8 / 1$ (white) & & \\
\hline 240,800 & $10 \mathrm{YR} 8 / 1$ (white) & 200 & $5 Y 8 / 1$ (white) & & \\
\hline 270,900 & 10YR 7.5/2 (light gray) & 200 & $2.5 \mathrm{Y}^{7} / 2$ (light gray) & 2000 & 10YR $8 / 1$ (white) \\
\hline 300,1000 & 5YR $6.5 / 1$ (gray) & 200 & 10YR $7.5 / 1$ (light gray) & 2000 & 10YR $9 / 1$ (white) \\
\hline
\end{tabular}

Table 5. Colors of modern, marine ostracode shells subjected to different T-P in the sediments listed.

\begin{tabular}{|c|c|c|c|c|}
\hline $\begin{array}{c}\text { T-P } \\
\left({ }^{\circ} \mathrm{C}, \mathrm{Atm} .\right)\end{array}$ & $\begin{array}{l}90 \% \text { calcite } \\
10 \% \text { siderite }\end{array}$ & $\begin{array}{l}75 \% \text { calcite } \\
25 \% \text { siderite }\end{array}$ & $\begin{array}{l}90 \% \text { calcite } \\
10 \% \text { hematite }\end{array}$ & $100 \%$ hematite \\
\hline 120,400 & $\begin{array}{l}5 \mathrm{YR} 7.5 / 1 \\
\quad \text { (white) }\end{array}$ & $\begin{array}{l}\text { 10YR } 7.5 / 2.5 \\
\text { (light gray) }\end{array}$ & $\begin{array}{l}2.5 \mathrm{Y} 8 / 3 \\
\text { (white) }\end{array}$ & $\begin{array}{l}\text { 10YR } 8 / 1 \\
\text { (white) }\end{array}$ \\
\hline 150,500 & $\begin{array}{c}5 \mathrm{YR} 8 / 2 \\
\text { (pinkish white) }\end{array}$ & $\begin{array}{l}\text { 5YR } 8 / 1 \\
\text { (white) }\end{array}$ & $\begin{array}{c}2.5 \mathrm{Y} 6.5 / 3 \text { to } 2.5 \mathrm{Y} 5.5 / 4 \\
\text { (light yellowish brown to light olive brown) }\end{array}$ & $\begin{array}{l}\text { 7.5YR } 8 / 2 \text { to } 5 \text { YR } 8 / 2 \\
\quad \text { (pinkish white) }\end{array}$ \\
\hline 180,600 & $\begin{array}{l}\text { 5YR } 7.5 / 2 \\
\text { (pinkish gray) }\end{array}$ & $\begin{array}{c}10 \mathrm{YR} 6.5 / 2 \\
\text { (light brownish gray) }\end{array}$ & $\begin{array}{c}2.5 \mathrm{Y} 6.5 / 4 \\
\text { (light yellowish brown) }\end{array}$ & No recovery \\
\hline 210,700 & $\begin{array}{l}\text { 10YR } 7.5 / 2 \\
\text { (light gray) }\end{array}$ & $\begin{array}{l}\text { 10YR } 8 / 1 \\
\text { (white) }\end{array}$ & $\begin{array}{l}2.5 \mathrm{Y} 7 / 1 \\
\text { (light gray) }\end{array}$ & $\begin{array}{c}5 \mathrm{YR} 5.5 / 3 \\
\text { (fragile, reddish brown) }\end{array}$ \\
\hline 240,800 & $\begin{array}{l}\text { 5YR } 8 / 1 \\
\text { (white) }\end{array}$ & $\begin{array}{l}\text { 10YR } 8 / 1 \\
\text { (white) }\end{array}$ & $\begin{array}{c}2.5 Y 7 / 2 \\
(\text { light gray) }\end{array}$ & No recovery \\
\hline 270,900 & $\begin{array}{l}\text { 5YR } 8 / 0 \\
\text { (white) }\end{array}$ & $\begin{array}{c}10 \mathrm{YR} 7.5 / 2 \\
\text { (light brownish gray) }\end{array}$ & $\begin{array}{l}10 \mathrm{YR} 7.5 / 3 \\
\text { (pale brown) }\end{array}$ & No recovery \\
\hline 300,1000 & No recovery & $\begin{array}{l}\text { 5YR } 6.5 / 1 \\
\text { (gray) }\end{array}$ & $\begin{array}{l}\text { 5YR } 9 / 1 \\
\text { (white) }\end{array}$ & $\begin{array}{c}\text { 10YR } 7 / 2 \\
\text { (light gray) }\end{array}$ \\
\hline
\end{tabular}


Table 6. Colors of modern, marine ostracodes tested in organicrich $(12.8 \%)$ bayou sediment at T-P listed.

\begin{tabular}{cc}
\hline \hline $\begin{array}{c}\text { T-P } \\
\left({ }^{\circ} \mathrm{C}, \text { Atm. }\right)\end{array}$ & Color \\
\hline 120,400 & \\
150,500 & $10 \mathrm{YR} 5.5 / 2$ \\
& (grayish brown) \\
180,600 & $2.5 \mathrm{Y} 5.5 / 2$ \\
& $($ grayish brown) \\
210,700 & $10 \mathrm{YR} 2.5 / 2$ to $10 \mathrm{YR} 3.5 / 2$ \\
240,800 & (very dark brown to very dark grayish brown) \\
& $10 \mathrm{YR} 3 / 2$ \\
270,900 & (very dark grayish brown) \\
300,1000 & $2.5 \mathrm{Y} 6 / 2$ \\
& (light brownish gray) (?ostracode) \\
& $10 \mathrm{YR} 2 / 2$ \\
& (very dark brown)
\end{tabular}

some outcrops were compared with colors of shells from rocks with known thermal histories to determine how temperature may alter shell color.

We herein define dark to mean those colors with Munsell values of less than 5 in the range from 0 to 10 , which represent absolute black to absolute white, respectively (Munsell Soil Color Charts, 1988).

All specimens are housed in the Department of Geosciences, Northeast Louisiana University.

\section{RESULTS AND DISCUSSION}

Modern, untreated, unaltered, marine specimens are white $(5 \mathrm{Y} 8 / 1$ to $5 \mathrm{Y} 8 / 1.5)$ to pale yellow $(2.5 \mathrm{Y} 8 / 4)$. Upon heating at atmospheric pressure up to about $650^{\circ} \mathrm{C}$, they became redder in hue, darker (lower values) and lost color saturation (chroma); that is, shells changed to $5 \mathrm{Y}$ $7.5 / 2$ (white or light gray) to 5YR 5.5/1 (gray) to $10 \mathrm{YR} 8 /$ 1 (white). Above $650^{\circ} \mathrm{C}$ and up to about $800^{\circ} \mathrm{C}$ they became lighter again and more yellow. Above about $850^{\circ} \mathrm{C}$ shells retained their general shape and outline and became even more yellow, chalky, or flaky (see Table 2). We interpret these changes to indicate that the materials in the organic network of the shell and the epicuticle (Bate \& East, 1972) were driven off before the temperature reached $650^{\circ} \mathrm{C}$ and that calcite began to deteriorate at about $850^{\circ} \mathrm{C}$ (Gross, 1971).

Marine shells subjected to elevated T-P with pure sediments of either quartz, calcite, or Elf clay showed no overall tendencies to change hue, value, or chroma (Table 3; Figures $1,10-1,11)$. In 25 percent calcite and 75 percent quartz, at increments of $30^{\circ} \mathrm{C}$ and $100 \mathrm{~atm}$., they became redder, darker, and more color saturated than untreated specimens; less alteration took place when the pressure was maintained at a low level, 200 atm. In trials at the highest pressure $(2,000 \mathrm{~atm}$.) the shells appeared to be severely bleached. Pressure, then, seems to have a positive relationship with the degree of alteration of color of the ostracode shell (Table 4).

As outlined in Table 5, marine shells in different iron compounds were also subjected to elevated temperatures and pressures. Shells in 90 percent calcite and 10 percent siderite became markedly redder in hue and their chromas increased up to $210^{\circ} \mathrm{C}$ (decreasing at higher temperatures), but they showed no significant differences in value. Shells treated in 75 percent calcite and 25 percent siderite became redder and showed no consistent trend in color value (lightness or darkness) or in chroma. In 90 percent calcite and 10 percent hematite, shells eventually became redder and less color saturated (chroma) with increasing T-P. In 100 percent hematite with elevated T-P, shells became redder and somewhat darker but showed little change in color saturation (i.e., overall the change was white to reddish brown to light gray). Although some alteration

Table 7. Colors of modern, freshwater ostracodes (Cypridopsis sp.) tested in sediment from Bayou Desiard with calcite as a control, at T-P listed.

\begin{tabular}{|c|c|c|c|}
\hline $\begin{array}{c}\text { T-P } \\
\left({ }^{\circ} \mathrm{C}, \mathrm{Atm} .\right)\end{array}$ & Calcite & $\begin{array}{c}\text { Bayou sediment; } \\
\text { some soft-parts in shells }\end{array}$ & $\begin{array}{l}\text { Bayou sediment; } \\
\text { without soft-parts in shells }\end{array}$ \\
\hline 120,400 & 10YR 5.5/2 (gray) & - & 10YR $4.5 / 3$ (brown) \\
\hline 150,500 & 5YR $8 / 1$ (white) & 10YR 5.5/2 (grayish brown) & 2.5YR $3.5 / 2$ (dusky red) \\
\hline 180,600 & 10YR $8 / 1$ (white) & $2.5 \mathrm{Y} 4.5 / 2$ (dark grayish brown) & 2.5 Y $4.5 / 4$ (olive brown) \\
\hline 210,700 & 10YR 8/1 (white) & 7.5YR 3.5/0 (very dark gray) & $5 Y 2.5 / 1$ (black) \\
\hline 240,800 & 10YR $8 / 1$ (white) & $10 \mathrm{YR} 2.5 / 2$ (very dark gray) & $5 Y 2.5 / 1$ (black) \\
\hline 270,900 & 10YR $8 / 1$ (white) & 10YR 2/1 (black) (?shell) & 10 YR $4.5 / 3$ (brown) \\
\hline 300,1000 & 10YR $8 / 1$ (white) & No recovery & 10YR $4.5 / 2$ (dark grayish brown) (?shell) \\
\hline$?=$ probably & & & \\
\hline
\end{tabular}




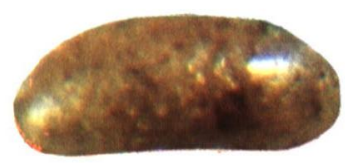

1

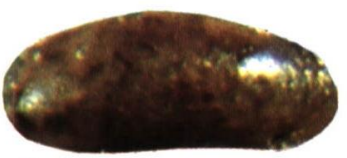

5

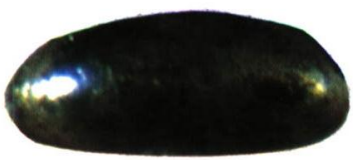

9

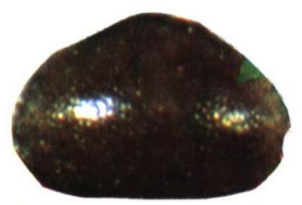

13

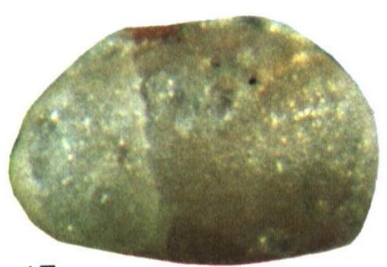

17

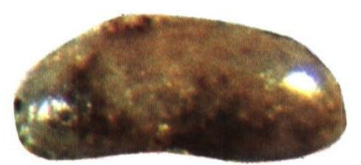

2

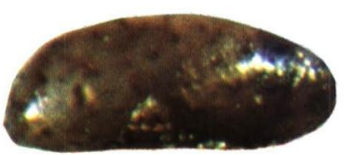

6

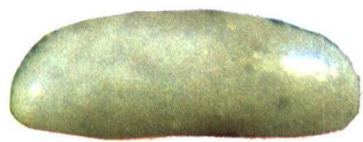

10

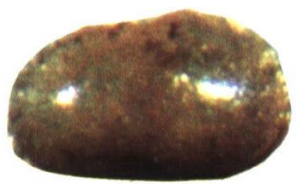

14

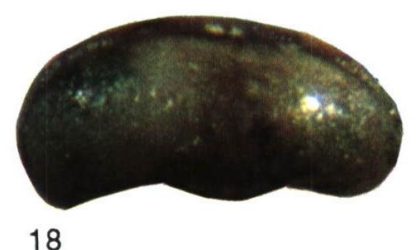

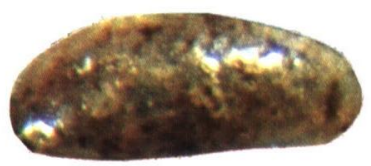

3

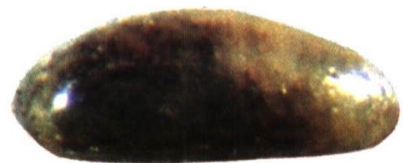

7

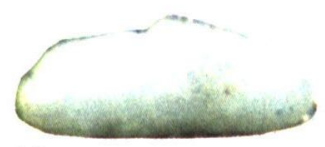

11

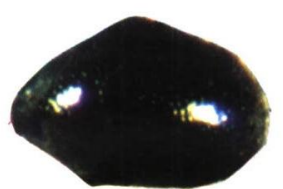

15

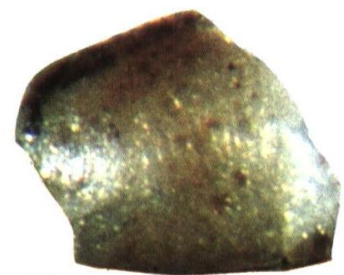

19

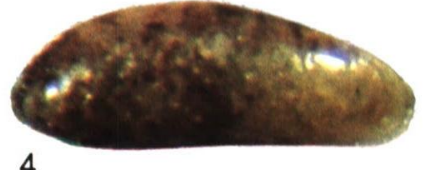

4

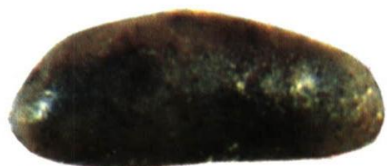

8

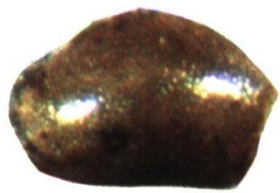

12

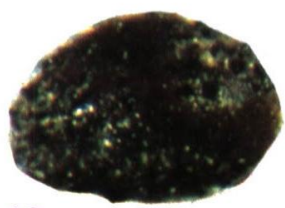

16

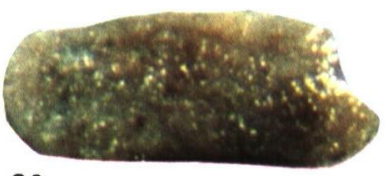

20

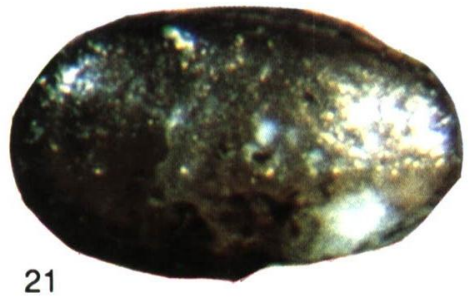

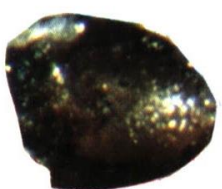

22

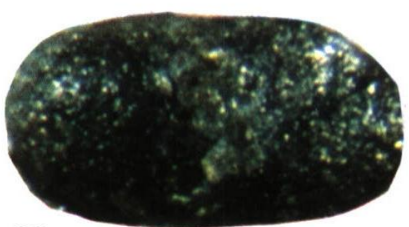

23

Fig 1. Individual specimens photographed on the Munsell gray mask card; photos were trimmed and mounted on Crescent Illustration Board \#110 ("white"). All specimens shown at magnification of 45X._-1-9. Hemicytherideis elongata (Brady), treated at temperature and pressure indicated in quartz and crude oil; 1 , treated at $120^{\circ} \mathrm{C}, 400$ atm., 2 , treated at $150^{\circ} \mathrm{C}, 500$ atm., $3,180^{\circ} \mathrm{C}$, 600 atm., $4,210^{\circ} \mathrm{C}, 700$ atm., 5, $240^{\circ} \mathrm{C}, 800$ atm., $6,270^{\circ} \mathrm{C}, 900$ atm., $7,300^{\circ} \mathrm{C}, 1000$ atm., $8,330^{\circ} \mathrm{C}, 1100$ atm., $9,360^{\circ} \mathrm{C}, 1200$ atm.-10-11. Hemicytherideis elongata (Brady), treated in quartz and distilled water only; $10,120^{\circ} \mathrm{C}, 400 \mathrm{~atm} ., 11,300^{\circ} \mathrm{C}, 1000$ atm._12-16. Cypridopsis sp., treated in organic-rich bayou sediment; $12,120^{\circ} \mathrm{C}, 400 \mathrm{~atm} ., 13,150^{\circ} \mathrm{C}, 500 \mathrm{~atm} ., 14,180^{\circ} \mathrm{C}, 600 \mathrm{~atm}$, $15,210^{\circ} \mathrm{C}, 700 \mathrm{~atm} ., 16,270^{\circ} \mathrm{C}, 900 \mathrm{~atm} . \longrightarrow 17-23$. Various Cretaceous ostracodes from Elf-Agip Congo borehole BGM-1; 17 , from depth of 1415-1440 meters, 18, fragment, 1650-1660 m, 19, fragment, 1920-1940 m, 20, fragment, 2060-2070 m, 21, 2125-2145 m, 22 , fragment, $2200-2210 \mathrm{~m}, 23,2455-2465 \mathrm{~m}$. 
Table 8. Colors of modern, marine ostracode shells heated in an oven at $50^{\circ} \mathrm{C}$ at atmospheric pressure, with crude oil (API $46^{\circ}$ ); sediments as listed.

\begin{tabular}{|c|c|c|c|}
\hline Time (hours) & quartz & calcite & Elf clay \\
\hline 24 & $2.5 \mathrm{Y} 6.5 / 6$ (olive yellow) & $2.5 \mathrm{Y} 6.5 / 6$ (olive yellow) & $2.5 Y 5.5 / 6$ (olive) \\
\hline 48 & $2.5 \mathrm{Y} 4.5 / 2$ (olive gray) & $2.5 \mathrm{Y} 4 / 2$ (olive gray) & $2.5 \mathrm{Y} 5.5 / 2$ (olive gray) \\
\hline 72 & $2.5 \mathrm{Y} 3.5 / 2$ (dark olive gray) & $2.5 \mathrm{Y} 4 / 2$ (olive gray) & $2.5 \mathrm{Y} 5 / 2$ (olive gray) \\
\hline 96 & $2.5 Y 5.5 / 4$ (olive) & 10YR 4/3 (olive) & $2.5 Y 4.5 / 3$ (olive) \\
\hline 120 & $2.5 Y 5.5 / 4$ (olive) & $2.5 \mathrm{Y} 4.5 / 4$ (olive) & $2.5 \mathrm{Y} 6.5 / 4$ (pale olive) \\
\hline 144 & $2.5 \mathrm{Y} 4.5 / 4$ (olive) & 10YR 4/4 (olive) & 10YR 6/3 (pale brown) \\
\hline 168 & 2.5 Y $6 / 4$ (light yellowish brown) & 10YR 4/4 (dark yellowish brown) & $10 \mathrm{YR} 5.5 / 3$ (brown) \\
\hline 192 & $2.5 Y 5 / 4$ (light olive brown) & $10 \mathrm{YR} 3 / 6$ (dark yellowish brown) & $10 \mathrm{YR} 5 / 3$ (brown) \\
\hline 216 & $2.5 Y$ 6.5/2.5 (light brownish gray) & 10YR $3 / 6$ (dark yellowish brown) & 10YR 5/3 (brown) \\
\hline 240 & 2.5 Y $5.5 / 3$ (grayish brown) & 5YR 3.5/3.5 (dark red brown) & 7.5YR 6.5/4 (light brown) \\
\hline 264 & 7.5YR 6.5/4 (light brown) & 10YR 3.5/4 (dark yellowish brown) & 7.5YR 4.5/4 (dark brown) \\
\hline 432 & 7.5YR 5.5/2 (brown) & 10YR 3.5/4 (dark yellowish brown) & 7.5YR 6/4 (grayish brown) \\
\hline
\end{tabular}

Table 9. Colors of modern, marine ostracode shells heated in crude oil (API $46^{\circ}$ ) at temperatures shown and atmospheric pressure.

\begin{tabular}{cccc}
\hline \hline Temp. $\left({ }^{\circ} \mathrm{C}\right)$ & Quartz & Calcite & Elf Clay \\
\hline 190 to 200 & 10YR 4.5/3.5 (brown) & 10YR $5.5 / 3$ (brown) & 10YR 6.5/3.5 (pale brown) \\
316 to 371 & 10YR 4.5/3 (dark brown) & 10YR $5.5 / 3$ (brown) & 10 YR $6.5 / 2$ (light brownish gray) \\
371 to 425 & 10YR 7.5/1.5 (light gray) & 10YR 5.5/1 (gray) & $2.5 Y 5.5 / 2$ (grayish brown) \\
\hline
\end{tabular}

Table 10. Colors of modern, marine ostracode shells in calcite or quartz sediment, with crude oil (API $\left.46^{\circ}\right)$ at T-P listed.

\begin{tabular}{|c|c|c|}
\hline T-P $\left({ }^{\circ} \mathrm{C}\right.$, Atm. $)$ & Calcite & Quartz \\
\hline 120,400 & - & $2.5 \mathrm{Y} 6 / 4$ (light olive brown) \\
\hline 150,500 & 10YR $6.5 / 4$ (light yellowish brown) & 10YR 5/4 (yellowish brown) \\
\hline 180,600 & 10YR $6.5 / 4$ (light yellowish brown) & 10YR 4.5/2 (dark grayish brown) \\
\hline 210,700 & 10YR 5.5/4 (yellowish brown) & 10YR $3.5 / 3$ (dark brown) \\
\hline 240,800 & 10YR $6.5 / 4$ (light yellowish brown) & 10YR $4.5 / 3$ (brown) \\
\hline 270,900 & 10YR $6.5 / 2.5$ (light brownish gray) & 10YR $4.5 / 3$ (brown) \\
\hline 300,1000 & 10YR 6/3 (pale brown) & 10YR $2.5 / 2$ (very dark brown) \\
\hline 330,1100 & - & 10YR 3/1 (very dark brown) \\
\hline 360,1200 & 10YR $8 / 1$ (white) & $5 Y 2.5 / 1$ (black) \\
\hline
\end{tabular}

was expected and attained with these iron compounds, the shells were not changed to the dark grays, dark browns, and blacks that characterize many fossil ostracodes. Indeed, at none of the temperatures and pressures in the experiments described above did the ostracodes change to the dark colors seen in some fossils.

Marine ostracode shells in the bayou sediment, which contains 12.8 percent organic matter, underwent changes that resulted in dark colors like those of some fossils. They became redder and darker but maintained the same chroma (2). Initially, specimens became grayish brown (10YR $5.5 / 2$ to $2.5 Y 5.5 / 2)$ from $150^{\circ} \mathrm{C}$ at 500 atm. to $180^{\circ} \mathrm{C}$ at $600 \mathrm{~atm}$., while at higher T-P shells became very dark grayish brown to very dark brown (10YR 3/2 to 10YR 2/2) (Table 6).

Prior to testing, freshwater specimens were white to pale yellow (2.5Y 7.5/2.5). When mixed with sediment from Bayou Desiard and subjected to elevated T-P, freshwater ostracodes with soft parts (Cypridopsis sp.) became much darker and slightly less color saturated, then redder 
Table 11. Colors of Early Cretaceous ostracode shells from the Yanguas-Arnedillo, northeastern Spain; paleotemperatures interpreted from metamorphic rocks. Temperature presumed to increase from top to bottom of table (temperature data from $\mathrm{H}$. J. Oertli, personal communication, 1984).

\begin{tabular}{|c|c|c|}
\hline Temp. $\left({ }^{\circ} \mathrm{C}\right)$ & Sample no. & Color \\
\hline \multirow{7}{*}{ less than 150} & 271 & $2.5 \mathrm{Y} 5.5 / 2$ (grayish brown) \\
\hline & 268 & $2.5 Y 3.5 / 1$ (very dark gray) \\
\hline & 235 & $2.5 \mathrm{Y} 3.5 / 1$ (very dark gray) \\
\hline & 216 & $5 Y 2.75 / 2$ (very dark grayish brown) \\
\hline & 131 & no specimens \\
\hline & 30 & no specimens \\
\hline & 8 & $5 Y 2.75 / 2$ (very dark grayish brown) \\
\hline \multirow[t]{4}{*}{200} & 3696 & $5 Y 4 / 3$ (olive) \\
\hline & 3556 & $5 Y 2.5 / 1.5$ (black) \\
\hline & 3511 & $2.5 Y 2 / 1$ (black) \\
\hline & 3375 & $2.5 \mathrm{Y} 2 / 1$ (black) \\
\hline \multirow[t]{4}{*}{200 to 350} & 3320 & $2.5 Y 2 / 1$ (black) \\
\hline & 3230 & $2.5 Y 2.5 / 0$ (black) \\
\hline & 3072 & $2.5 Y 2.5 / 0$ (black) \\
\hline & 3020 & 2.5 Y $2.5 / 0$ (black) \\
\hline \multirow[t]{3}{*}{350} & 2852 & $2.5 Y 2.5 / 0$ (black) \\
\hline & 2689 & $2.5 \mathrm{Y} 3 / 0$ (very dark gray) \\
\hline & 2550 & $2.5 \mathrm{Y} 3 / 0$ (very dark gray) \\
\hline \multirow{3}{*}{$\begin{array}{l}\text { greater than } \\
\qquad 350\end{array}$} & 2415 & $2.5 \mathrm{Y} 3 / 0$ (very dark gray) \\
\hline & 2336 & $\begin{array}{l}2.5 Y 3.5 / 0 \text { (very dark gray) } \\
\text { possibly recrystallized }\end{array}$ \\
\hline & 2161 & no specimens \\
\hline
\end{tabular}

and less color saturated. The colors (grays, browns, blacks) are similar to those of some fossils (Table 7; Figures 1,12$1,16)$. In sediment from Bayou Desiard, ostracodes without soft parts first became redder, then yellower, then redder, but in all instances as T-P increased they became darker, with colors about equal to the dark reds, browns, and blacks characteristic of many fossil ostracodes. Freshwater ostracodes in pure calcite (a control) became slightly redder, then white $(10 \mathrm{YR} 8 / 1)$, with little color saturation, showing none of the profound changes that took place with the bayou sediment (Table 7).

It is interesting to note that freshly collected, marine and freshwater algae as well as leaves and twigs of deciduous trees caused all shells to be destroyed at temperatures and pressures greater than or equal to $120^{\circ} \mathrm{C}$ and 400 atm.; that is, there was no recovery of the shells placed in the vessels with these organic materials. The sediment from Bayou Desiard obviously included organic material already altered; the gross organic structures were not identifiable at a magnification of $100 \mathrm{X}$. It was not nearly as destructive to the calcareous shells as was the fresh organic material.
As indicated in Table 8, tests demonstrated that crude oil can be a coloring agent. Over time, from 24 to 432 hours, at one atm. and $50^{\circ} \mathrm{C}$ in crude oil (API $46^{\circ}$ ), marine specimens in quartz and oil became redder, darker, and more color saturated. They changed progressively to olive yellow to light olive brown to brown. In calcite and oil, shells became redder and darker, then dark yellowish brown. In Elf clay and oil, shells became redder and darker, becoming light olive brown, pale brown, and light brown. Again, these colors are common among fossil ostracodes. The shells treated in crude oil at atmospheric pressure at $50^{\circ} \mathrm{C}$ were then aged at room temperature and pressure for an additional 2,880 hours, which caused no further changes in color.

Specimens heated with quartz and crude oil at higher temperatures (and still at atmospheric pressure) first became redder, darker, and more color saturated and then became lighter and less color saturated above $371^{\circ} \mathrm{C}$. Those heated in calcite and Elf clay showed little change in value, but they lost color saturation (chroma) at higher temperatures (Table 9; Figures 1,1-1,9).

Shells heated in calcite and crude oil at elevated temperature and elevated pressure became darker, and more color saturated up to about $210^{\circ} \mathrm{C}, 700 \mathrm{~atm}$.; at higher T-P shells retained the same hue, but became lighter and had lower color saturation (Table 10). In quartz and oil, specimens became redder and even darker than in calcite and then lost color saturation (chroma) at about $300^{\circ} \mathrm{C}, 1000$ atm. These colors, too, are similar to the colors of many fossil ostracodes and more or less simulate the downhole distribution of colors of specimens from some wells (see Tables 14-17).

As mentioned above, many ostracode fossils have colors similar to those resulting from heating in crude oil or organic-rich sediments. In a section of Early Cretaceous argillaceous rocks from the Yanguas-Arnedillo area of northeastern Spain (Table 11), approximate paleotemperatures were interpreted from metamorphic mineral

Table 12. Results of reheating (at atmospheric pressure) colored Cretaceous ostracode shells from sample 3320 of the YanguasArnedillo section of northeastern Spain; color of fossils was $2.5 \mathrm{Y}$ 2/0 (black).

\begin{tabular}{cc}
\hline \hline Temp. $\left({ }^{\circ} \mathrm{C}\right)$ & Color \\
\hline 100 & $7.5 \mathrm{YR} 2.5 / 0$ (very dark gray to black) \\
200 & $7.5 \mathrm{YR} 2 / 0$ (black) \\
$300-325$ & $7.5 \mathrm{YR} 2 / 0$ (black) \\
$400-425$ & $7.5 \mathrm{YR} 3 / 0$ (very dark gray) \\
$490-510$ & $7.5 \mathrm{YR} 3.5 / 0$ (very dark gray) \\
$600-625$ & $7.5 \mathrm{YR} 3.5 / 0$ (very dark gray) \\
$675-725$ & $7.5 \mathrm{YR} 3.5 / 0$ (very dark gray) \\
800 & $7.5 \mathrm{YR} 6.5 / 0$ (light gray) \\
900 & $10 \mathrm{YR} 8 / 1$ (white) \\
\hline
\end{tabular}


Table 13. Colors of Cretaceous ostracode shells after experimental reheating at atmospheric pressure. Shells were dark grayish brown (2.5Y 3.5/2) as recovered from 1650 to $1660 \mathrm{~m}$ (Barremian) in Elf-Agip Congo borehole BGM-1 (from Zaire).

\begin{tabular}{|c|c|c|}
\hline Temp. $\left({ }^{\circ} \mathrm{C}\right)$ & Color & Remarks \\
\hline 100 & $\begin{array}{c}\text { 10YR } 3 / 1 \\
\text { (very dark gray) }\end{array}$ & \\
\hline 200 & $\begin{array}{c}7.5 \mathrm{YR} \quad 3.5 / 0 \\
\text { (very dark gray) }\end{array}$ & \\
\hline $300-325$ & $\begin{array}{r}7.5 \mathrm{YR} 3.5 / 2 \\
\text { (dark brown) }\end{array}$ & \\
\hline $400-425$ & $\begin{array}{r}7.5 \mathrm{YR} 4.5 / 2 \\
\text { (dark brown) }\end{array}$ & \\
\hline $490-510$ & $\begin{array}{c}\text { 5YR 4.5/1 } \\
\text { (dark gray) }\end{array}$ & \\
\hline $600-625$ & $\begin{array}{c}5 Y 4.5 / 2 \\
\text { (dark reddish gray) }\end{array}$ & \\
\hline 700 & $\begin{array}{l}\text { 7.5YR } 6.5 / 1 \\
\text { (gray) }\end{array}$ & $\begin{array}{l}\text { Flaky, cracked, has darker } \\
\text { internal mold }\end{array}$ \\
\hline 800 & $\begin{array}{l}7.5 \mathrm{YR} 6.5 / 1 \\
\text { (gray) }\end{array}$ & Cracked, frosty \\
\hline 900 & $\begin{array}{l}\text { 7.5YR } 8 / 0 \\
\text { (white) }\end{array}$ & $\begin{array}{l}\text { Flaky, remnants do not } \\
\text { effervesce in } 5 \% \mathrm{HCl}\end{array}$ \\
\hline
\end{tabular}

suites; ostracode shells were differently colored from one temperature zone to another (Oertli, personal communication, 1984; Kontrovitz \& De Hon, 1986). In the rocks interpreted as having been subjected to temperatures less than $150^{\circ} \mathrm{C}$, shell color was in the range from $2.5 \mathrm{Y} 5.5 / 2$ (grayish brown) to 5 Y 2.75/2 (very dark grayish brown ); at temperatures of about $200^{\circ} \mathrm{C}$ the shell color was $5 \mathrm{Y} 4 / 3$ (olive). From about $200^{\circ} \mathrm{C}$ to less than $350^{\circ} \mathrm{C}$ colors were $5 Y 2.5 / 1$ to $2.5 \mathrm{Y} 2.5 / 0$ (black). At about $350^{\circ} \mathrm{C}$ the color was $2.5 \mathrm{Y} 2.5 / 0$ (black). Shells presumably subjected to temperatures higher than $350^{\circ} \mathrm{C}$ were slightly less color saturated (Table 11).

Some specimens from northeastern Spain that were reheated in the laboratory changed to new colors. For example, those from locality 3320 , which were colored very dark gray to black (7.5YR 2.5/0), began to lighten at about $400^{\circ} \mathrm{C}$ (Table 12). Those from boreholes showed similar changes, as exemplified by shells from Cretaceous sediments from Zaire (Table 13). These shells were originally dark grayish brown (2.5Y 3.5/2); upon heating, they began to lighten at about $400^{\circ} \mathrm{C}$, indicating that the coloring agent had been driven off by heat.

Fossil ostracodes from boreholes in Cretaceous rocks from Zaire, Gabon, and Senegal, have downhole differences of color similar to those produced in the laboratory experiments (Tables 14, 15, 16; Figures 1,17-1,23). Shells from boreholes in Mesozoic and early Tertiary sediments from the Fastnet basin and the southern region of the north Celtic Sea have colors that indicate thermal maturation (Table 17). "For the thirty-four wells studied, twentyseven contained sufficient ostracod samples to form colour profiles ... for each well. A summary of the alteration ... illustrates that ostracod colour is largely independent of initial ... lithology and is a product of subsequent thermal influences" (Ainsworth et al., 1990). It should be noted that all fossils were readily soluble in 5 percent $\mathrm{HCl}$, yielding an amorphous mass of organic material similar to that from modern forms (Sohn, 1958).

Igneous rocks and sulphide mineralization implying thermal activity were noted in some wells of the Irish and $\mathrm{U}$. K. offshore areas. In the three wells with thick igneous intrusions, ostracode color and vitrinite reflectance show the strong influence of the sills that extends over a thickness that is three to four times that of the intrusion (Ainsworth et al., 1990; see Table 17).

The colors of nonpyritized fossil shells were unaffected after 336 hours in such common organic solvents as benzene, acetone, xylene, and ethyl alcohol. Those so treated and other nonpyritized fossils were all bleached to white or pale yellow when heated above 375 to $450^{\circ} \mathrm{C}$, as indicated above. This fact and the result showing that modern ostracodes develop dark colors only when heated in an organic-rich substance tend to support the contention that they are darkly colored by extraneous, matured, organic materials. Upon heating, pyritized shells become reddish (weak red; 10R 4/4); thus they can be distinguished from those we interpret to be colored by organic compounds.

\section{SUMMARY AND CONCLUSIONS}

(1) Modern ostracode shells subjected to elevated temperatures and pressures change colors but never attain the dark colors seen in many fossils.

(2) Only shells treated in mature, extraneous, organic matter, including petroleum, develop the dark colors similar to those of many fossils.

Table 14. Ostracode colors from Neocomian to Barremian sediments in the Elf-Agip Congo borehole BGM-1 (from Zaire).

\begin{tabular}{|c|c|c|}
\hline Depth (m) & Color & Remarks \\
\hline $1415-1440$ & $5 Y 7.5 / 2$ (light gray) & ?mold \\
\hline $1650-1660$ & 10YR 4.5/2 (dark grayish brown) & ?shell \\
\hline $1920-1940$ & 10YR $6 / 2$ (light brownish gray) & ?shell \\
\hline $2060-2070$ & 10YR 5.5/2 (grayish brown) & ?mold \\
\hline $2125-2145$ & $10 \mathrm{YR} 2 / 2$ (very dark brown) & ?mold \\
\hline $2200-2210$ & 10YR 2/1 (black) & ?mold \\
\hline $2455-2465$ & no specimens & - \\
\hline $3358-3368$ & $5 Y 2 / 1$ (black) & ?shell \\
\hline $3610-3620$ & $5 Y 2.5 / 1$ (black) & ?shell \\
\hline$?=$ probabl & & \\
\hline
\end{tabular}


Table 15. Ostracode colors from Cretaceous sediments in the Shell-Gabon/Elf-Gabon CRM-1 borehole.

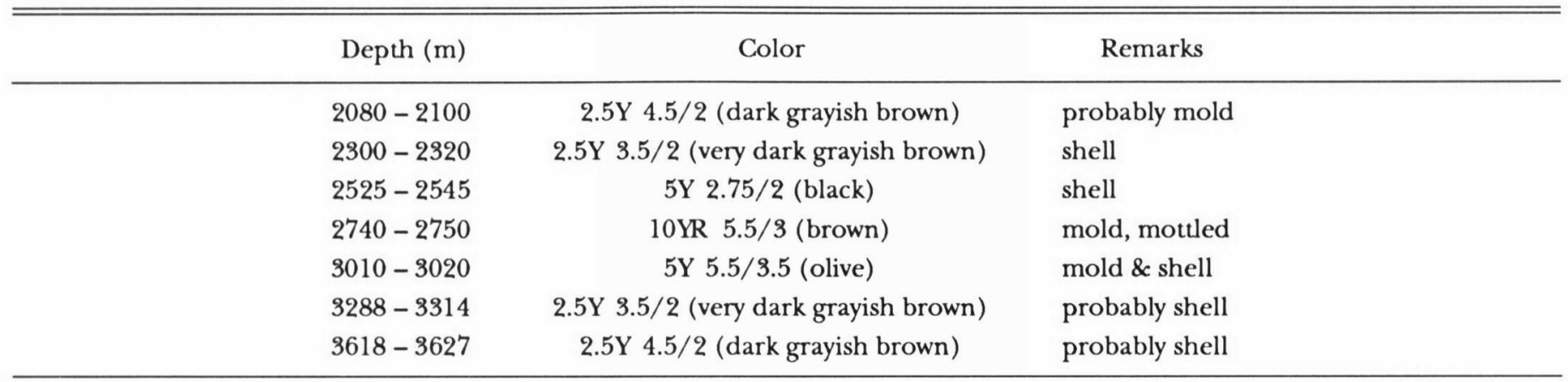

Table 16. Ostracode colors from Neocomian, Coniacian, and Santonian sedimentary rocks from the Elf KAF-1 Senegal borehole.

\begin{tabular}{|c|c|}
\hline Depth $(\mathrm{m})$ & Color \\
\hline 1345 & $2.5 Y 5.5 / 4$ (light olive brown) \\
\hline 1945 & $5 \mathrm{Y} 4.5 / 2$ (olive gray) (?ostracode) \\
\hline 2360 & $5 \mathrm{Y} 2 / 2.0$ to $2.5 \mathrm{Y} 5 / 2$ (black to olive gray) \\
\hline 2752 & $5 Y 3 / 1$ (very dark gray) \\
\hline 3340 & $5 Y 2.5 / 2$ to $5 Y 3.5 / 2$ (black to dark olive gray) \\
\hline 3730 & $5 Y 2.5 / 2$ to $5 Y 3.5 / 2$ (black to dark olive gray) \\
\hline 4120 & $5 \mathrm{Y} 2.5 / 1$ to $5 \mathrm{Y} 3 / 2$ (black to dark olive gray) \\
\hline 4528 & $5 \mathrm{Y} 3 / 1$ to $5 \mathrm{Y} 3.5 / 2$ (very dark gray to dark olive gray) \\
\hline 5020 & $5 Y 2.5 / 1$ (black) \\
\hline 5280 & $5 Y 3.5 / 2$ (dark olive gray) \\
\hline
\end{tabular}

Table 17. Colors of ostracode shells from the Gulf 56/18-1 well, northern Fastnet Basin, offshore Ireland (modified from Table 1 of Ainsworth, Burnett, \& Kontrovitz, 1990).

\begin{tabular}{|c|c|}
\hline Depth $(\mathrm{m})$ & Color (mean) \\
\hline 1768 & $2.5 \mathrm{Y} 8 / 4$ to $10 \mathrm{YR} 8 / 4$ (very pale yellow to very pale brown) \\
\hline 1813 & $2.5 \mathrm{Y} 8 / 4$ to $10 \mathrm{YR} 8 / 4$ (very pale yellow to very pale brown) \\
\hline 1908 & $2.5 \mathrm{Y} 8 / 4$ to $10 \mathrm{YR} 6 / 6$ (very pale yellow to brownish yellow) \\
\hline 1969 & 10YR 6/6 (brownish yellow) \\
\hline 2170 & 10YR $6 / 6$ to $10 \mathrm{YR} 4 / 6$ (brownish yellow to dark yellowish brown) \\
\hline 2201 & 10YR 4/6 (dark yellowish brown) \\
\hline 2274 & 10YR $4 / 6$ to $5 \mathrm{YR} 3 / 4$ (dark yellowish brown to dark reddish brown) \\
\hline 2441 & $10 \mathrm{YR} 4 / 6$ to $10 \mathrm{YR} 2 / 1$ (dark yellowish brown to black) \\
\hline 2727 to 2856 & Thick basic sill \\
\hline 3005 & *neutral 2/0 (black) \\
\hline 3155 & 2.5 Y $3 / 2$ to *neutral $2 / 0$ (very dark gray black to black) \\
\hline 3243 & 10YR 4/6 to $5 \mathrm{YR} 5 / 6$ (dark yellowish brown to dark reddish brown) \\
\hline 3272 & Thin basic sill \\
\hline 3397 & Thin basic sill \\
\hline 5593 & $10 \mathrm{YR} 4 / 6$ to $5 \mathrm{YR} 5 / 6$ (dark yellowish brown to dark reddish brown) \\
\hline
\end{tabular}


(3) Iron compounds other than pyrite cause only light and poorly saturated colors in ostracode shells.

(4) Highly colored ostracode shells mark areas near igneous rocks and in metamorphic rocks; colors are diagnostic of the level of thermal alteration.

(5) Fossil ostracodes from some boreholes have downhole color differences similar to those obtained experimentally.

(6) Darkly colored fossils reheated in the laboratory undergo new color changes; they begin to lighten markedly at about 375 to $400^{\circ} \mathrm{C}$, eventually becoming pale yellow or white, thereby indicating that organic compounds caused the coloration (Gross, 1971).

(7) Upon heating, pyritized shells become reddish (weak red; 10R 4/4); thus they can be distinguished from those colored by organic compounds, which whiten upon heating.

(8) The dark colors of fossils are different (hue, value, chroma) in different thermal zones, and ostracode color appears to be broadly diagnostic of thermal history.

Acknowledgments.-Dr. Henri J. Oertli, formerly with Société Nationale Elf Aquitaine, Pau, supplied the Elf clay and ostracode specimens from the beach of Rimini (Italy), northeastern Spain, and the boreholes in Africa. Dr. Zhao Yuhong, formerly of the Nanjing Institute of Geology and Palaeontology, Academia Sinica, P.R. China, collected some of the freshwater material from Louisiana. James B. Mann, an NLU graduate student, assisted with some of the laboratory work; and Colin Kimball, a former NLU graduate student, provided the crude oil.

We thank Dr. Roger L. Kaesler, The University of Kansas, and Dr. Rosalie F. Maddocks, University of Houston, who reviewed an earlier version of this article; their comments and suggestions greatly improved the study. We also thank Dr. Ronald E. Smith, Dean, College of Pure and Applied Science, NLK, for financial support for this paper.

\section{REFERENCES}

Ainsworth, N. R., R. D. Burnett, \& M. Kontrovitz. 1990. Ostracod colour change by thermal alteration, offshore Ireland and western U. K. Marine and Petroleum Geology 7:288-297.
Bate, R. H., \& B. A. East. 1972. The structure of the ostracode carapace. Lethaia 6(2):177-194.

Epstein, A. G., J. B. Epstein, \& L. D. Harris. 1977. Conodont color alteration-an index to organic metamorphism. United States Geological Survey Professional Paper 995. 27 p.

Garrels, R. M., \& F. T. Mackenzie. 1971. Evolution of Sedimentary Rocks. W. W. Norton \& Co. New York. 397 p.

Gross, M. G. 1971. Carbon determination, p. 573-596. In R. E. Carver, ed., Procedures in Sedimentary Petrology. WileyInterscience. New York.

Kontrovitz, M., N. R. Ainsworth, R. D. Burnett, \& Y. Zhao. 1989. Induced shell color of foraminifera: an aspect of taphonomy and potential paleotemperature indicator. Geological Society of America, Abstracts with Programs 22(6):A62.

Kontrovitz, M., \& R. A. De Hon. 1986. The use of ostracode shells to interpret the paleotemperature of some metamorphic rocks, p. A26. In Fourth North American Paleontological Convention, Abstracts. University of Colorado. Boulder, Colorado.

Kontrovitz, M., R. A. De Hon, \& J. H. Myers. 1982. Simulated burial of ostracode shells: progressive alteration, p. 96-103. In R. F. Maddocks, ed., Applications of Ostracoda. Department of Geology, University of Houston. Houston, Texas.

Kontrovitz, M., J. B. Mann, \& S. Barnett. 1988. Ostracode shell color: a potential paleotemperature indicator. Geological Society of America, Abstracts with Programs 20(7):A221.

Munsell Soil Color Charts. 1988 edition. MacBeth Division of Kollmorgen Instruments Corp. Baltimore, Maryland. 18 p.

Oertli, H. J. 1971. The aspect of ostracode faunas-a possible new tool in petroleum geology, p. 137-147. In H. J. Oertli, ed., Colloque sur la Paleoecologie des Ostracodes, Bulletin Centre Recherches Pau-SNPA.

Rejebian, V. A., A. J. Harris, \& J. S. Huebner. 1987. Conodont color and textural alteration: an index to regional metamorphism, contact metamorphism, and hydrothermal alteration. Geological Society of America Bulletin 99(4):471-479.

Sohn, I. G. 1958. Chemical constitutents of ostracodes: some applications to paleontology and paleoecology. Journal of $\mathrm{Pa}$ leontology 32:730-736.

Tway, L. E., W. E. Harrison, \& J. Zidek. 1986. Thermal alteration of microscopic fish remains-an initial study. Palaios 1:75-79.

Wilson, L. R. 1961. Palynological fossil response to low-grade metamorphism in Arkoma basin. Tulsa Geological Society Digest 29:131-140. 